\title{
The clinical study of congenital looped/ coiled peripapillary retinal vessels
}

\begin{abstract}
Purpose To present clinical manifestations of eyes with peculiar looped/coiled peripapillary retinal vessels.

Methods Seven patients with looped/coiled retinal vessels on or near the optic disc were enrolled. All patients went through detailed ophthalmologic examinations and fluorescein angiography (FAG).

Results There were two men and five women. Patients' age ranged from 15 to 71 years (mean: 39 years). The follow-up period ranged from 3 to 74 months (average: 27 months). One patient had bilateral involvement. Five of the seven patients noticed sudden onset of floaters in one eye. The colour fundus photography revealed looped/coiled retinal vessels on or near the optic disc, and most of the vessels were arteries. Accompanied retinal, preretinal, or vitreous haemorrhage was noted in all five patients who had sudden onset of floaters. Fluorescein angiography showed no leakage from the looped/coiled retinal vessels. No specific underlying diseases were noted in any patients. Follow-up examination revealed reabsorption of haemorrhage, and no change of the abnormal vessel patterns in any eyes. Conclusions The peculiar fundus lesion of looped/coiled peripapillary retinal vessels is likely a benign congenital retinal vascular anomaly that does not progress. Floaters secondary to preretinal or vitreous haemorrhage is the most frequent complaint. The prognosis is excellent.

Eye (2005) 19, 906-909. doi:10.1038/sj.eye.6701691; published online 24 September 2004
\end{abstract}

${ }^{1}$ Department of Ophthalmology Buddhist Xindian Tzu Chi General Hospital Taipei, Taiwan

\section{${ }^{2}$ Department of} Ophthalmology National Taiwan University Hospital

Taipei, Taiwan

\section{Correspondence:}

Chung-May Yang

Department of

Ophthalmology

National Taiwan University

Hospital, No.7

Chung Shan South Road

Taipei 100

Taiwan.

Tel: +886223123456

ext. 5187

Fax: +886 223412875

E-mail: chungmay@

ha.mc.ntu.edu.tw

Received: 13 April 2004 Accepted: 14 July 2004 Published online:

24 September 2004

There are no proprietary interests or research funding.
Keywords: retinal vascular anomaly; looped/ coiled peripapillary retinal vessels; vascular loop

\section{Introduction}

Various types of congenital anomalies of retinal vessels may occur, including hereditary retinal artery tortuosity, inherited retinal venous beading, hereditary haemorrhagic telangiectasis, congenital prepapillary vascular loops, congenital retinal macrovessels, and arteriovenous communications. ${ }^{1}$ Some involve the disc and the surrounding area; others may involve the entire vascular tree. We herein report a peculiar type of retinal vascular anomaly in which the involved retinal vessels are main branches of central retinal vessels that show looped or coiled patterns around or near the optic disc, with normal vascular structure in the other areas. No specific underlying diseases contributing to the development of this vascular anomaly were noted. Literature review showed only one similar case being briefly described. ${ }^{1}$ We collected seven cases with this kind of retinal vascular anomaly, and studied its clinical course, complication and associated anomalies.

Patients and methods

From 1996 to 2003, a total of seven cases with the diagnosis of looped and coiled peripapillary vascular anomaly were retrospectively reviewed. Visual symptoms and their relationship with exertion or trauma, systemic diseases, and drug-taking history were recorded. Thorough ophthalmological evaluations including best-corrected visual acuity, intraocular pressure, and anterior segment and posterior segment abnormalities were recorded in each visit. Fundus photography and fluorescein angiography were performed in the initial visit and at least once during follow-up visit.

\section{Results}

There were two men and five women. Age ranged between 15 and 71 years, with an average of 39 years. Follow-up period ranged from 3 to 74 months, with an average of 27 months. In these seven cases, six occurred 
unilaterally, and one (Case 4) occurred bilaterally (Figure 1). All seven cases had one or more arterial branches involved, a feature confirmed either by tracing the courses of those abnormal vessels or by fluorescein angiographic studies. Only one out of the seven (Case 2) also had venous branches involved. Five cases presented with sudden onset of floaters, and two were found during health examination. Retinal, preretinal, and/or vitreous haemorrhage near the vessel loops or coils could be seen in the five cases presenting with floaters.

Posterior vitreous detachment was found in only one case. No vitreous-disc traction or epipapillary membranes were noted in any cases. The optic disc was

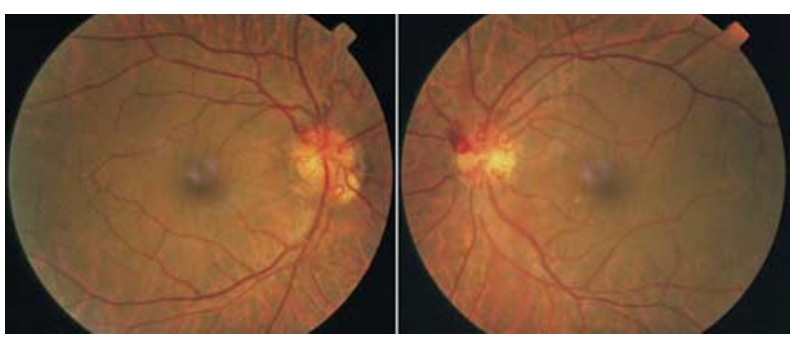

Figure 1 The colour fundus photographs of both eyes of Case 4 on the first visit. Looped/coiled peripapillary retinal vessels appeared in both eyes, and preretinal haemorrhage around the abnormal vasculature was noted in the left eye. otherwise normal in all except one (Case 2) that had situs invertus anomaly of the optic disc in the involved eye. No obvious predisposing factors such as trauma, Valsalva manoeuvre or blood pressure fluctuation were noted in these patients. The results of fluorescein angiography in all cases revealed no vessel leakage. One case had an episode of recurrent haemorrhage from the looped/coiled vessels. The age, sex, refraction status, and other associated findings were listed in Table 1. No single factor relating to the development of this vascular anomaly was noted. Here we presented a typical case (Case 1).

\section{Case 1}

A 41-year-old woman visited our outpatient clinic on 4 September, 1996 due to sudden onset of floaters in her right eye. On examination, the best-corrected visual acuity was $20 / 20$ in both eyes. The intraocular pressure was within normal range bilaterally. The anterior segments of both eyes were normal on slit-lamp biomicroscopy. Examination of the right fundus showed several narrow-calibred looped or coiled peripapillary retinal vessels with small amount of superficial retinal and preretinal haemorrhage adjacent to the disc (Figure 2, left). The left fundus was normal. Fluorescein

Table 1 Demographic and clinical data of seven cases of congenital looped/coiled peripapillary retinal vessels

\begin{tabular}{|c|c|c|c|c|c|c|c|c|c|c|}
\hline & $\begin{array}{l}\text { Age } \\
\text { (years) }\end{array}$ & Sex & $\begin{array}{l}\text { Follow-up } \\
\text { period }\end{array}$ & Symptoms & $\begin{array}{l}\text { Lesion } \\
\text { eye(s) }\end{array}$ & $B C V A$ & $\begin{array}{l}\text { Spherical } \\
\text { equivalent (D) }\end{array}$ & $\begin{array}{l}\text { Involved } \\
\text { vessels }\end{array}$ & $\begin{array}{l}\text { Accompanied } \\
\text { haemorrhage }\end{array}$ & Associations \\
\hline 1 & 35 & $\mathrm{~F}$ & 6 y $2 \mathrm{~m}$ & $\begin{array}{l}\text { Sudden onset of } \\
\text { floaters }\end{array}$ & od & $\begin{array}{l}\text { od: } 20 / 20 \\
\text { os: } 20 / 20\end{array}$ & $\begin{array}{l}\text { od: }-0.5 \\
\text { os: }-0.75\end{array}$ & A & $\begin{array}{l}\text { Retinal and } \\
\text { preretinal } \\
\text { haemorrhage }\end{array}$ & \\
\hline 2 & 38 & $\mathrm{~F}$ & $4 \mathrm{y} 10 \mathrm{~m}$ & $\begin{array}{l}\text { Sudden onset of } \\
\text { floaters }\end{array}$ & od & $\begin{array}{l}\text { od: } 20 / 20 \\
\text { os: } 20 / 20\end{array}$ & $\begin{array}{l}\text { od: }-1.5 \\
\text { os: }-5\end{array}$ & A \& V & $\begin{array}{l}\text { Preretinal } \\
\text { haemorrhage }\end{array}$ & $\begin{array}{l}\text { Situs invertus of } \\
\text { the optic disc, } \\
\text { PVD }\end{array}$ \\
\hline 3 & 40 & $\mathrm{~F}$ & $3 y$ & $\begin{array}{l}\text { Sudden onset of } \\
\text { floaters }\end{array}$ & od & $\begin{array}{l}\text { od: } 20 / 22 \\
\text { os: } 20 / 22\end{array}$ & $\begin{array}{l}\text { od: }-3.25 \\
\text { os: }-2.75\end{array}$ & A & $\begin{array}{l}\text { Preretinal and } \\
\text { vitreous } \\
\text { haemorrhage }\end{array}$ & $\begin{array}{l}\text { Systemic lupus } \\
\text { erythematosus }\end{array}$ \\
\hline 4 & 59 & $\mathrm{M}$ & $9 \mathrm{~m}$ & $\begin{array}{l}\text { Sudden onset of } \\
\text { floaters (os) }\end{array}$ & ou & $\begin{array}{l}\text { od: } 20 / 22 \\
\text { os: } 20 / 17\end{array}$ & $\begin{array}{l}\text { od: }+0.25 \\
\text { os: } 0\end{array}$ & A & $\begin{array}{l}\text { Preretinal } \\
\text { haemorrhage } \\
\text { (os) }\end{array}$ & $\begin{array}{l}\text { Systemic } \\
\text { hypertension }\end{array}$ \\
\hline 5 & 15 & $\mathrm{~F}$ & $6 \mathrm{~m}$ & $\begin{array}{l}\text { Sudden onset of } \\
\text { floaters }\end{array}$ & od & $\begin{array}{l}\text { od: } 20 / 22 \\
\text { os: } 20 / 20\end{array}$ & $\begin{array}{l}\text { od: }-1 \\
\text { os: }-1\end{array}$ & A & $\begin{array}{l}\text { Preretinal and } \\
\text { vitreous } \\
\text { haemorrhage }\end{array}$ & $\begin{array}{l}\text { Cilioretinal } \\
\text { artery }\end{array}$ \\
\hline 6 & 71 & $\mathrm{M}$ & $5 \mathrm{~m}$ & Nil & od & $\begin{array}{l}\text { od: } 20 / 200 \\
\text { os: } 20 / 50\end{array}$ & $\begin{array}{l}\text { od: }+2.5 \\
\text { os: }+2\end{array}$ & A & Nil & $\begin{array}{l}\text { DM with mild } \\
\text { NPDR (ou), } \\
\text { systemic } \\
\text { hypertension, } \\
\text { senile cataract } \\
\text { (ou) }\end{array}$ \\
\hline 7 & 16 & $\mathrm{~F}$ & $3 \mathrm{~m}$ & Nil & os & $\begin{array}{l}\text { od: } 20 / 20 \\
\text { os: } 20 / 20\end{array}$ & $\begin{array}{l}\text { od: }-4 \\
\text { os: }-5.25\end{array}$ & A & Nil & \\
\hline
\end{tabular}

A: arteries, BCVA: best-corrected visual acuity, DM: diabetes mellitus, m: months, NPDR: non-proliferative diabetic retinopathy, od: right eye, os: left eye, ou: both eyes, PVD: posterior vitreous detachment, V: veins, y: years. 


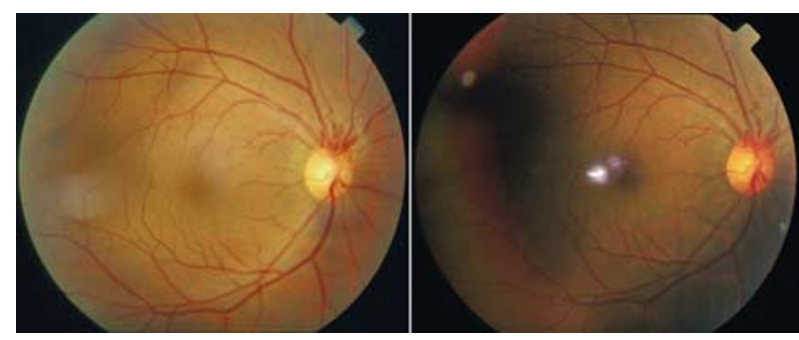

Figure 2 The colour fundus photographs of the right eye of Case 1 on the first and the last visit, respectively. No change of the vascular pattern was noted between the picture on the first visit (left) and that on the last visit (right).

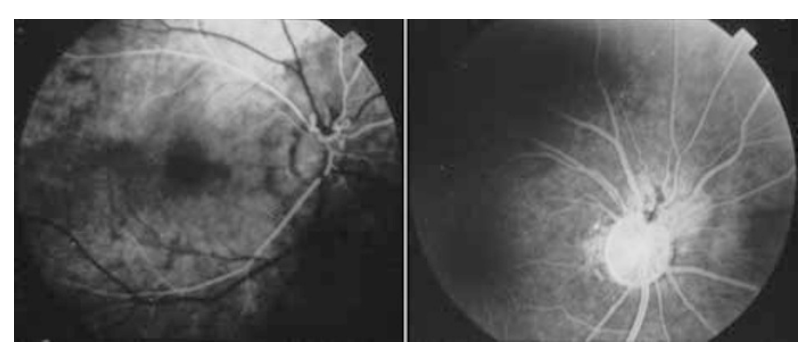

Figure 3 The fluorescein angiography of Case 1 (left: early phase; right: late phase) showed that all the abnormal vessels were on the arterial site.

angiography revealed that all the looped/coiled peripapillary retinal vessels on the right fundus were part of the branches of the central retinal artery. No leakage was noted from the looped/coiled vessels (Figure 3). Follow-up examination on 14 December, 1996 showed that the retinal and preretinal haemorrhage had been absorbed. Examination of the right fundus on 29 November, 2002 showed no change of the vascular pattern compared with that on the initial examination (Figure 2, right).

\section{Discussion}

The clinical pictures in our cases resemble those described under the diagnosis of congenital prepapillary vascular loop. However, there are several differences between these two. In prepapillary vascular loops, despite the fact that histopathological study suggested that the vascular loops derive from the retinal arterial system rather than from the hyaloid artery, the abnormal vessels are not part of the main retinal vasculature. They usually rise into the vitreous, may form one or more twists, and then return to the vessels on the optic disc or occasionally to some retinal branches. In our series, the anomalous vascular loops or coils are part of the main retinal vasculature. They stayed on the plane of the retina and did not protrude into the vitreous. Furthermore, most of our cases had more than one vascular loop or coil involved, in contrast to those with prepapillary loops where only one vascular loop was usually affected. Nevertheless, both entities may show similar clinical features secondary to blood stream turbulence and vascular torsion, ${ }^{3}$ such as localized retinal haemorrhage, preretinal haemorrhage, and vitreous haemorrhage. However, severe complications that may occur in prepapillary vascular loops such as retinal artery occlusion, hyphaema, and amaurosis fugax were not seen in this series. ${ }^{4-6}$ Perhaps the degree of vascular twisting is greater in some cases of prepapillary vascular loops.

Racemose aneurysms should also be considered in the differential diagnosis. This vascular anomaly is characterized by direct arteriovenous communications with usually dilated anomalous vessels. In contrast, none of our cases showed this feature. In our case 2, although there were two anomalous looped/coiled vessels involving venous branches, they were only involved segmentally and the other parts of the vessels appeared normally. None of the anomalous looped/coiled vessels communicated directly with each other. Hereditary retinal arteriolar tortuosity, another congenital anomaly with tortuous retinal vessels, affects primarily the medium-sized and smaller retinal arterioles, ${ }^{7}$ which also could be differentiated from our cases. Optociliary shunts may also mimic the pictures in our cases; they are, however, primarily venous in nature, and are not part of the main retinal vasculature.

Gass ${ }^{1}$ has shown a case of congenital arterial malformation in a young asymptomatic woman with coiled peripapillary arteries similar to what we described in this series. He also showed another case with congenital venous loop. In our seven cases, although most were young when the diagnosis was made, one case was identified at the age of 71 years; while most had involvement only on the arterial site, one case had both arterial and venous involvement, and none had isolated venous involvement. It is unknown if the isolated venous anomaly represents the other end of a continuous spectrum of the same disease or belongs to a different disease category.

Although in case 3, the patient had systemic lupus erythematosus, and in case 6 , the patient had diabetes with mild nonproliferative diabetic retinopathy in the same eye as the looped/coiled peripapillary retinal vessel existed, the vascular loops or coils in both cases showed no leakage on fluorescein angiograms and no other evidence of vascular occlusion was noted. Therefore, we believe this entity is not related to these two systemic vascular diseases.

During the follow-up periods, there was no morphological change of the vessels in any of these 
patients. Also, we did not find any associated ophthalmic or systemic diseases that could account for these findings. Therefore, we strongly believe that the looped/ coiled peripapillary retinal vessels are congenital in origin, although we can not prove this directly. Retinal, preretinal, and vitreous haemorrhage may complicate this situation; spontaneous resorption of the blood is the rule, and the prognosis is excellent.

\section{References}

1 Gass JDM. Stereoscopic Atlas of Macular Diseases: Diagnosis and Treatment, 4th ed. Mosby: St. Louis, MO, 1997, pp 438-443.
2 Shakin EP, Shields, JA, Augsburger JJ, Brown GC. Clinicopathologic correlation of a prepapillary vascular loop. Retina 1988; 8: 55-58.

3 Mireskandari K, Bentley C. Bilateral prepapillary loops with unilateral branch retinal artery occlusion following thrombus at the loop apex. Retina 2001; 21: 66-67.

4 Brucker AJ, Michels RG, Fine SL. Congenital retinal arterial loops and vitreous hemorrhage. Am J Ophthalmol 1977; 84: 220-223.

5 Degenhart W, Brown GC, Augsburger JJ, Magargal L. Prepapillary vascular loops. Ophthalmology 1981; 88: 1126-1131.

6 Zaharia M, Olivier P. Congenital retinal arterial loop and vitreous hemorrhage. Ophthalmologie 1988; 2: 315-319.

7 Wells CG, Kalina RE. Progressive inherited retinal arteriolar tortuosity with spontaneous retinal hemorrhages. Ophthalmology 1985; 92: 1015-1024. 